\title{
3 Agriculture in Salinising Landscapes in Southern Australia
} Selected Research 'Snapshots'

\author{
Edward G. Barrett-Lennard \\ and Hayley C. Norman
}

\section{CONTENTS}

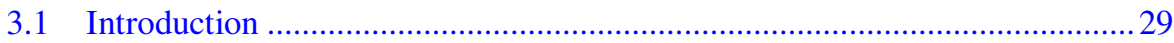

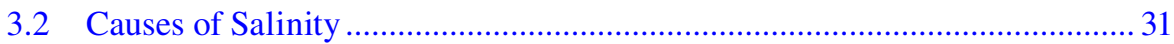

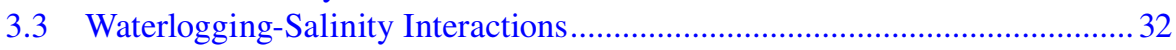

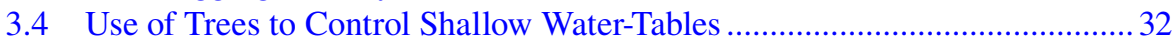

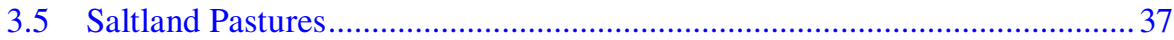

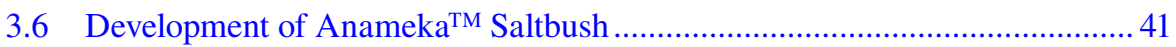

3.7 Electromagnetic Induction as a Tool in Conducting Field Trials ................... 41

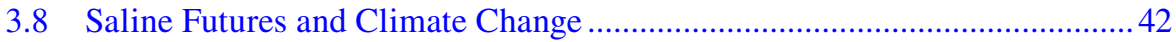

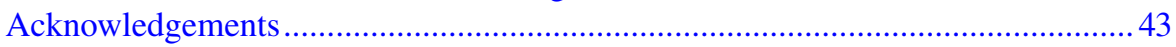

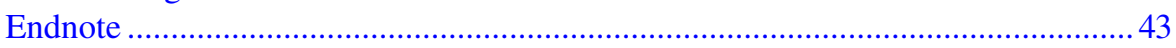

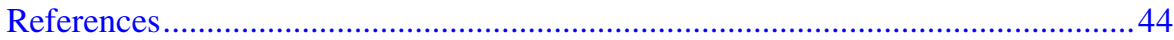

\subsection{INTRODUCTION}

Annual crops and pastures are widely grown in the $250-600 \mathrm{~mm}$ rainfall zone of Australia under non-irrigated conditions. This non-irrigated land can be affected by two salinity problems: salinity induced by the presence of a shallow water-table caused by the removal of the original forest (often called 'dryland' salinity) and that caused by soil dispersion due to sodicity and soil alkalinity (often called 'transient' salinity) (Rengasamy 2006; Barrett-Lennard et al. 2016). The former stress is caused by the formation of semi-permanent shallow water-tables and affects the growth of agricultural crops in all years. By contrast, the latter stress affects crop growth particularly in dry years, when the salt concentration in the soil increases, the water content of the soil decreases and the salinity of the soil solution is therefore elevated. The levels of salinity associated with these stresses can be very different. Soils affected by transient salinity typically fall into the slightly to moderately saline 


\section{TABLE 3.1 \\ Categorisation of Salinity in Australia in Terms of the $\mathrm{EC}_{\mathrm{e}}$ Ranges That Fall into the following $\mathrm{EC}_{1: 5}$ Ranges (by Soil Texture)}

$\begin{array}{lc}\text { Term } & \mathbf{E C}_{\mathbf{e}} \text { Range }(\mathbf{d S} / \mathbf{m}) \\ \text { Non-saline } & 0-2 \\ \text { Slightly saline } & 2-4 \\ \text { Moderately saline } & 4-8 \\ \text { Highly saline } & 8-16 \\ \text { Severely saline } & 16-32 \\ \text { Extremely saline } & \geq 32\end{array}$

\begin{tabular}{ccc}
\multicolumn{3}{c}{$\mathbf{E C}_{\mathbf{1 : 5}}$ Range for Different Soil Textures } \\
\hline For Sands & For Loams & For Clays \\
$0-0.14$ & $0-0.18$ & $0-0.25$ \\
$0.15-0.28$ & $0.19-0.36$ & $0.26-0.50$ \\
$0.29-0.57$ & $0.37-0.72$ & $0.51-1.00$ \\
$0.58-1.14$ & $073-1.45$ & $1.01-2.00$ \\
$1.15-2.28$ & $1.46-2.90$ & $2.01-4.00$ \\
$\geq 2.29$ & $\geq 2.91$ & $\geq 4.01$
\end{tabular}

Source: After Barrett-Lennard et al. 2008.

range (Table 3.1), so these soils are generally sown to annual crops such as wheat, barley and canola. By contrast, those soils affected by dryland salinity often have salinities in the highly, severely and extremely saline ranges (Table 3.1), so these soils are generally reserved for the growth of saltland pastures based around the use of halophytes or are otherwise abandoned.

One issue that immediately confronts the reader wanting to obtain an overview of salinity in Australia - its scale, the kinds of research that have been conducted and the kinds of adaptations that communities have made - is that salinity is a State rather than a Federal issue, so the answers to these questions generally reside within State Government agencies, and integrated answers to questions at the national scale may be difficult to find. ${ }^{1}$ Nevertheless, there have been federal initiatives (such as the National Dryland Salinity Program, National Action Plan on Salinity and Water Quality and several Cooperative Research Centres) and networks of interstate collaboration (such as the National Program on the Utilisation and Rehabilitation of Saline Land - PURSL) that have enabled national collaborations and syntheses to be developed around particular issues.

The total area of land used for the growth of grain crops in Australia is 112 Mha (Rengasamy 2002). In 2002, the Australian Bureau of Statistics surveyed farmers at the national level about the extent of dryland salinity on agricultural land (Table 3.2). This showed that dryland salinity affected nearly 20,000 farms around Australia, nearly 2 Mha showed signs of salinity, 0.8 Mha were so severely affected that the land was not able to be productively used and that WA was the most severely affected State.

The areas of land associated with transient salinity (i.e. associated with dispersive soils) are not precisely known but might be substantially greater (Rengasamy, 2002). In regions where the salinity problem is greatest, many farmers manage mixed cropping and livestock systems with annual crops and sheep for meat and wool (Norman et al. 2016a). 


\section{TABLE 3.2}

\section{Results of National Australian Bureau of Statistics Survey of Extent of Dryland Salinity in 2002}

$\begin{array}{lccc}\text { State } & \begin{array}{c}\text { Number of Farms } \\ \text { with Salinity }\end{array} & \begin{array}{c}\text { Land Showing Signs } \\ \text { of Salinity ('000 ha) }\end{array} & \begin{array}{c}\text { Salinised Land Unable to Be } \\ \text { Used for Production ('000 ha) }\end{array} \\ \text { NSW } & 3108 & 124 & 44 \\ \text { Vic. } & 4834 & 139 & 60 \\ \text { Qld } & 993 & 107 & 40 \\ \text { SA } & 3328 & 350 & 105 \\ \text { WA } & 6918 & 1241 & 567 \\ \text { Tas. } & 390 & 6 & 2 \\ \text { NT } & 8 & 2 & 821 \\ \text { Total Australia } & 19,579 & 1,969 & \\ \text { Source: ABS 2002. } & & & \\ \end{array}$

\subsection{CAUSES OF SALINITY}

Salinity was recognised in Australia as an important constraint in catchments used to collect water for towns and cities from the early 1920s (Wood 1924) and in agricultural landscapes from the 1930s (Teakle and Burvill 1938). Beginning with Burvill (1956), a series of surveys of farmers in Western Australia conducted by the Australian Bureau of Statistics every 4-7 years showed that there was a continuing deterioration in the areas of previously arable land that became too saline to grow conventional crops and pastures. The effect of these surveys $(1955,1962,1979,1984$, 1989 , 2002) was to induce a strong level of community concern about the apparent inexorable increase in salinity with time.

The reputed causes of salinity in rainfed environments in Australia were initially confusing: today two causes are recognised. The most severe form of salinity, induced by the presence of a shallow water-table, is caused by the clearing of the original native forests, shrublands and perennial grasslands (which used virtually all the rainfall) and their replacement with annual crops and pastures (which used less than all the rain) (Wood 1924). Water-tables at the time of European settlement 100-150 years ago were $\sim 5-50 \mathrm{~m}$ below ground level. The net percolation of water deep into the soil caused a rise in water-table, bringing salt stored in the profile to the soil surface. When the water-table reached a critical depth, the land became too saline for the growth of annual crops and pastures. Nulsen (1981) provided a set of plausible, critical depths to the water-table for plants of different salt tolerance in the wheatbelt of Western Australia: $\sim 2.2 \mathrm{~m}$ for the growth of wheat crops, $\sim 1.8 \mathrm{~m}$ depth for the growth of barley crops and $\sim 1.5 \mathrm{~m}$ depth for the growth of salt-tolerant annual barley grass. The problems of shallow water tables in dryland (non-irrigated landscapes) are not confined to southern Australia alone: Ghassemi et al. (1995) note that have been reports of similar effects in the Great Plains region of North America, and in South Africa, Turkey, Thailand, India and Argentina. 
There were two important later elaborations were to this hydrological explanation of salinity. Firstly, it was recognised that groundwater flow, and therefore the expression of salinity, could be strongly influenced by geomorphic structures in the landscape (e.g. weathered dolerite dykes, bedrock highs, fractures in rock aquifers and the presence of semi-confining sedimentary layers; George et al. 1997). Secondly, it was recognised that the surface hydrology of soils was also important. In landscapes cleared of their original native vegetation, runoff from hillsides accumulated at low points in the landscape exacerbating groundwater rise (reviewed by Barrett-Lennard et al. 2005). However, the complication remained that in semi-arid areas salinity was not necessarily associated with the presence of shallow water-tables (Teakle and Burvill 1938). It later became clear that many Australian soils, particularly sodic alkaline clays of the semi-arid environment were naturally dispersive and could accumulate over hundreds of years the small amounts of salt that fell in the rain (Hingston and Gailitis 1975) to levels that impacted on crop growth in relatively dry years (Rengasamy 2006; Barrett-Lennard et al. 2016).

\subsection{WATERLOGGING-SALINITY INTERACTIONS}

A further level of complexity became apparent when it was realised that another by-product of shallow water-tables was seasonal waterlogging, and waterlogging interacted with salinity to further constrain crop growth. Empirical observations in the 1970s by an influential farmer named Harry Whittington (who later established a farming group of over 1000 members, WISALTS) suggested that the symptoms of salinity could be abated by surface water management by installation of throughflow interceptor banks (Conacher et al. 1983). Confusion therefore ensued: Whittington's supporters claimed that the implementation of the interceptor banks prevented salinity; however, the truth is that his 'interceptor banks' probably changed shallow soil hydrology, decreasing waterlogging. Research that began in the 1970s showed that in saline landscapes, waterlogging increased the uptake of $\mathrm{Na}^{+}$and $\mathrm{Cl}^{-}$, and decreased the uptake of $\mathrm{K}^{+}$by crop plants (reviewed by Barrett-Lennard 1986, 2003; BarrettLennard and Shabala 2013) and this knowledge helped settle the confusion. More recently, Bennett et al. (2009) have published a matrix suggesting that the ideal location for different crop and forage plants in salt-affected land can be determined by relating the general level of soil salinity and waterlogging in the landscape to the known tolerances of the plants to these two stresses. Today, the amelioration of waterlogging with shallow (and some deep) drainage, and the planting of appropriate crops and pastures with a combination of tolerances to salinity and waterlogging are regarded as the optimal solution for farming saline landscapes affected by shallow water-tables. The message to farmers that emerged from this was to 'put the right plant in the right location'.

\subsection{USE OF TREES TO CONTROL SHALLOW WATER-TABLES}

Agricultural systems in the rainfed landscapes of southern Australia are generally of low productivity due to the low rainfall and low fertility of these soils; expensive drainage options to lower water-tables are therefore unlikely to be adopted without 
substantial publicly funded subsidies. For this reason, there became a strong research focus on the use of perennial plants acting as forms of 'biological pumps' to lower water-tables. The first systematic attempt at this was through the planting of trees. The thinking was that if salinity was caused by the development of shallow watertables as a consequence of the clearing of deep-rooted native forests, then perhaps it could also be reversed by re-establishing trees back into the landscape. In a series of 'ventilated-chamber' experiments, Greenwood and colleagues were able to show that stands of trees were able to use water at rates in excess of local rainfall: this could only be possible if the plants were accessing local groundwater and therefore decreasing the risk of salinity in the landscape.

In one of these experiments (Greenwood et al. 1985), trees were established $\sim 6$ years earlier in two dense plantations in an area receiving $\sim 770 \mathrm{~mm}$ annual average rainfall; one plantation was near the top of a hill ( $\sim 8 \mathrm{~m}$ above the water-table) and the other was located mid-slope ( $\sim 5 \mathrm{~m}$ above the water-table). Evapotranspiration from the trees was measured for $24 \mathrm{~h}$ every 4 weeks for a year; this was used to estimate the annual evapotranspiration (summarised in Figure 3.1). Evapotranspiration was measured similarly from an adjacent annual pasture while it was green. It was found that annual evapotranspiration from the pasture accounted for $\sim 57 \%$ of annual rainfall over the year; the balance of the rainfall was clearly infiltrating into the deeper soil increasing the risk of salinity. By contrast, evapotranspiration from the trees accounted for 240-390\% of annual rainfall; the water used in excess of rainfall must have come from soils adjacent to the trees (Figure 3.1). The conclusion was that the trees were capable of using water in excess of rainfall and therefore decreasing salinity risk in the landscape.

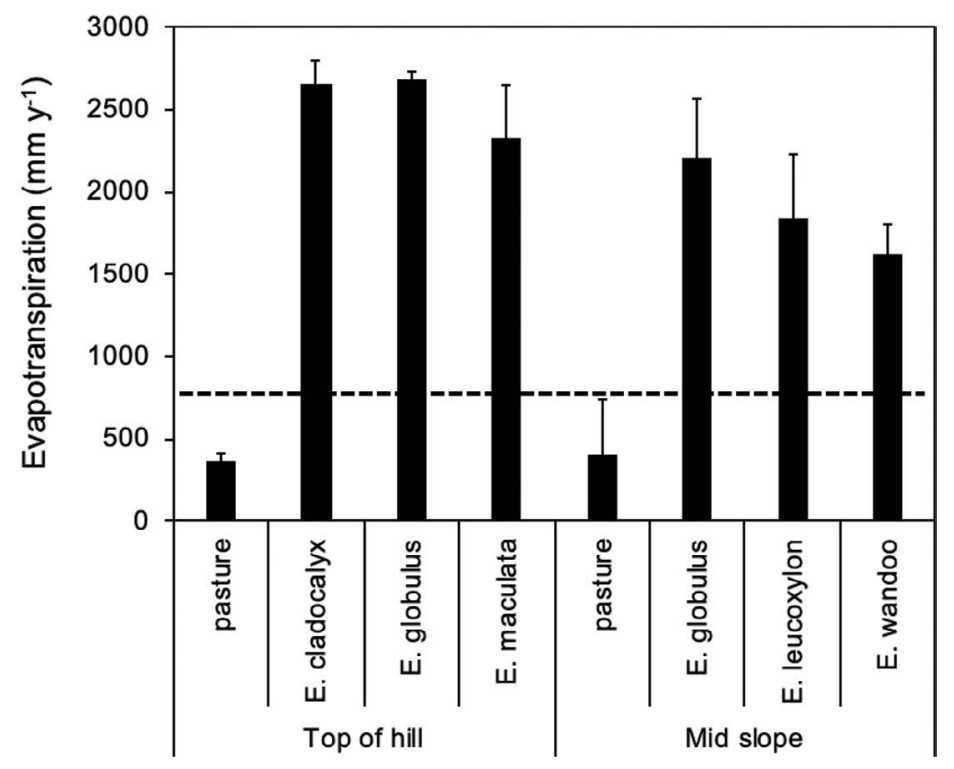

FIGURE 3.1 Annual evapotranspiration by annual pasture and stands of eucalyptus trees growing in a $770 \mathrm{~mm}$ annual average rainfall zone (dotted line) at two locations in Western Australia (After Greenwood et al. 1985). 
One problem with the use of relatively small areas of trees for short periods to estimate rates of tree water use is that as trees draw-down local water-tables there will generally be a mass flow of water from outside the plantation into the root-zone of the trees; this ensures high rates of water use in the short term. In general, the experiments of Greenwood et al. measured water use by small plots of trees over short intervals of time (1-2 years after establishment); their experiments, therefore, exaggerated the effects that trees might have on groundwater at catchment scales. To make the case more strongly what was needed were experiments that examined the effects of trees on depth to water-table (the key driver of salinity) planted over larger areas and measured over longer periods of time. A later paper (Bennett and George 2008) showed that in 24 investigations in catchments receiving $450-820 \mathrm{~mm}$ of average annual rainfall and where trees had been planted at a catchment scale for 10-21 years, there was a significant $(P<0.001)$ effect on the rate of water-table drawdown of the percent of a catchment with trees (i.e. remnant vegetation and revegetation) (Figure 3.2). On average to achieve a rate of water-table drawdown of $0.1 \mathrm{~m}$ per year, catchments needed to have $\sim 30 \%$ of their area covered by remnant vegetation and revegetation.

How large does a tree need to be to be able to use enough soil water to avert a salinity problem? $10 \mathrm{~m}$ ? What about $10 \mathrm{~cm}$ ? One of the interesting themes of research in Australia is that perennial pasture plants may be able to act as 'functional mimics' of trees and use enough water to dry soils, lower water-tables and prevent salinity (Hatton and Nulsen 1999). The critical factor here is not the height of the transpiring perennial plant but the depth of its root system. This has led to the notion of 'phase farming' (Latta et al. 2001, 2002), in which perennial pasture plants like lucerne (alfalfa) are grown on a field for 1-2 years to deplete stored soil water and these are

$\%$ catchment with trees (remant + vegetation)

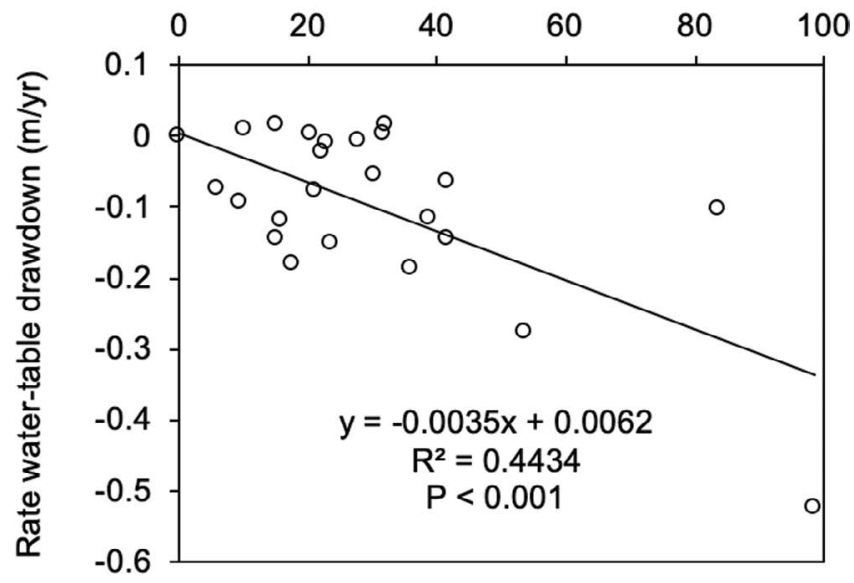

FIGURE 3.2 Effect of tree vegetation (remnant vegetation and revegetation) on the rate of water-table drawdown $(\mathrm{m} / \mathrm{yr})$ for catchment with a shallow water-table in Western Australia (After Bennett and George 2008). Rates of water-table drawdown were measured over periods of 10-21 years. 

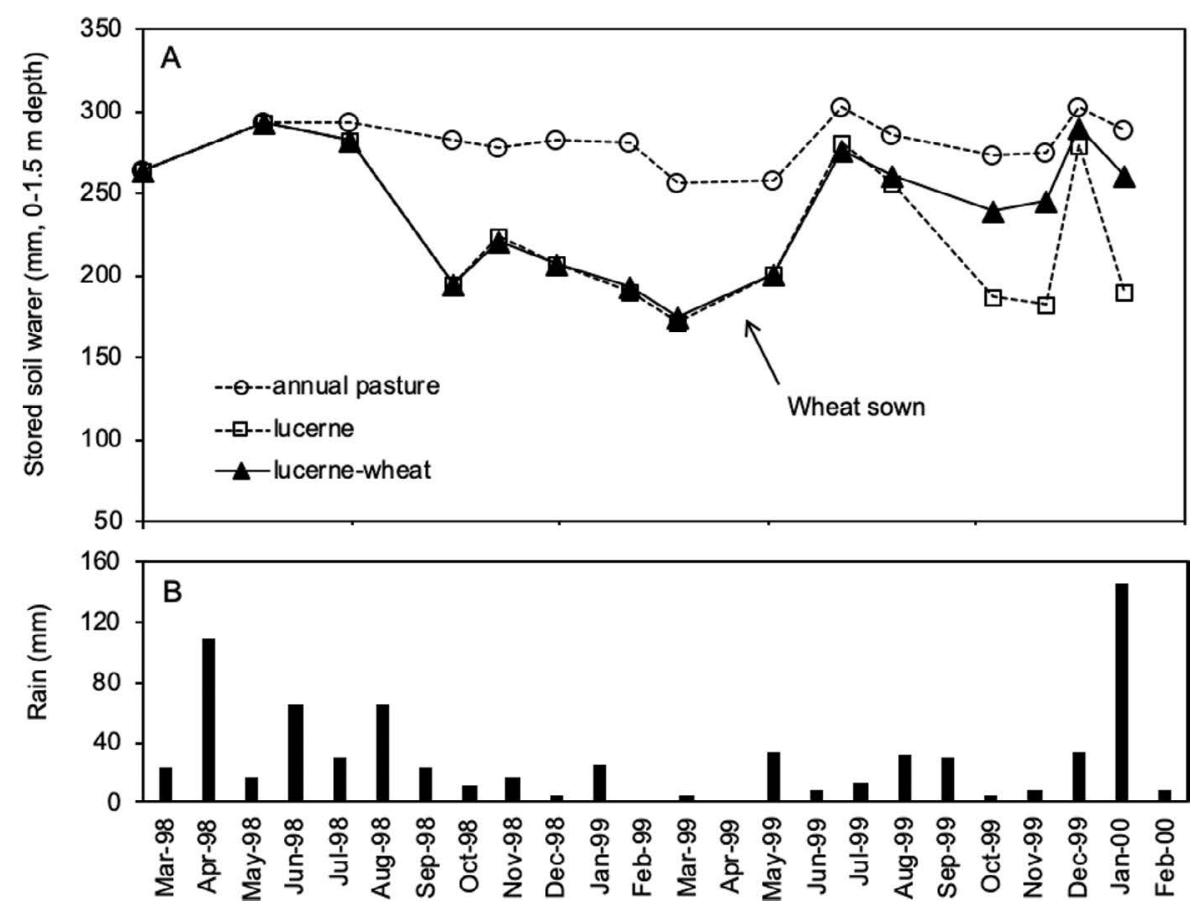

FIGURE 3.3 Results of phase farming trial at Newdegate (After Latta et al. 2002): (A) Amounts of water stored in the upper $1.5 \mathrm{~m}$ of the soil profile at a Newdegate field site when sown to an annual clover-based pasture, to lucerne, or to a lucerne-wheat rotation; and (B) Monthly rainfall at site (Bureau of Meteorology). Each treatment was replicated three times in a fully randomised block design. Plots were $12 \times 25 \mathrm{~m}$ in area. Wheat was sown at point indicated by arrow.

then replaced by more profitable annual grain crops for several years during which time the soil profile wets up again.

The concept can be illustrated using data from a typical field trial comparison of the soil water content in the upper $1.5 \mathrm{~m}$ of the soil profile beneath an annual pasture, a perennial lucerne pasture and a lucerne-wheat rotation (Latta et al. 2002). Figure 3.3 shows the variation over a 2 -year period in the amount of water stored in the upper $1.5 \mathrm{~m}$ of the soil profile when planted to these three options and the monthly rainfall. It can be seen that irrespective of monthly rainfall (Figure 3.3b) the soils planted to the annual pasture option contained $\sim 250-300 \mathrm{~mm}$ of water in the upper $1.5 \mathrm{~m}$ of the soil profile (Figure 3.3a). Presumably, this water content was close to the soil's drained upper limit, and rainfall in excess of that required to bring the soil to the drained upper limit percolated deeper into the soil profile. By contrast, once the lucerne pasture had established, the soils planted to this perennial had 20-100 mm less stored soil water in the soil profile; there would have been a less deep percolation of rainfall into the soil profile with this treatment. Finally, where the lucerne was replaced by wheat, there was an increase in soil water content; this 
option would have leaked water into the deeper soil profile. These observations led the researchers to conclude that the growth of lucerne alternating with wheat might be both a more sustainable and financially robust solution, with the wheat crops providing the bulk of the financial gain to the farmer, and the lucerne ensuring that the soils were periodically dried down, decreasing the long-term salinity outcomes in the landscape.

While plot- and catchment-scale research could show that perennial plants were capable of using groundwater, lowering water-tables and decreasing salinity, different (modelling) approaches were needed to determine the likely benefits of plant interventions at a landscape scale. One model used to do this was 'Flowtube' (Dawes et al. 2000). This is a simple two-dimensional model that can predict the likely impacts of any hydrological intervention (such as the implementation of perennial vegetation) in a 'slice' through a catchment (from the top of a hill to the bottom of a valley) on the depth to groundwater along that slice. In one study, models were built at three locations (in the 330, 400 and $600 \mathrm{~mm}$ annual rainfall zones of WA) to examine the expected long-term impacts of a series of plausible hydrological interventions (low, medium or high changes to the water balance) on groundwater depths along the flowtube (George et al. 2001). Simulations began with the present-day water-table depth profile in each catchment (as determined from piezometers) and continued at daily intervals for 100 years into the future. The model was calibrated by comparing the computed rates of groundwater rise along the flowtube with the historic measured rates of groundwater rise in piezometers in each catchment. What became clear from the simulations was that irrespective of the location, with the donothing scenario most (72-94\%) of each catchment was at risk of salinisation (i.e. a water-table less than $1 \mathrm{~m}$ in depth would occur within 100 years). Furthermore, even with low, moderate or high levels of hydrological intervention (defined in specific terms for each catchment), the outcomes in terms of land salinity remained challenging with $46-79 \%, 41-52 \%$ and $34-48 \%$ respectively of the three catchments being affected (Table 3.3). These predictions of salinity outcomes for non-irrigated landscapes, even with the implementation of major remedial farming practice change, remain as one of the most confronting commentaries on the sustainability of agriculture in southern Australia.

\section{TABLE 3.3}

\section{Percent of Flowtube with Water-Table Less than $1 \mathrm{~m}$ after 100 Years}

\author{
Rainfall (Location) \\ $330 \mathrm{~mm}$ (North Baandee) \\ $400 \mathrm{~mm}$ (Toolibin) \\ $600 \mathrm{~mm}$ (Date Creek)
}

Hydrological Intervention

\begin{tabular}{cccc}
\hline None & Low & Moderate & High \\
89 & 79 & 52 & 34 \\
94 & 62 & 61 & 48 \\
72 & 46 & 41 & 38
\end{tabular}

Source: After George et al. 2001. 


\subsection{SALTLAND PASTURES}

If salinity cannot be cheaply avoided by revegetating farmland with perennial vegetation (trees and pastures) then can it be lived with? One of the obvious ways to obtain production from saline land is to plant it to salt-tolerant plants (halophytes) that have value as forages for ruminant livestock (such as sheep and cattle). Australian researchers and farmers have been working collaboratively to incorporate salttolerant forages into their farming systems for more than 80 years. Some of the key dates and events associated with the development of herbaceous species and halophytic shrubs for saltland pastures are summarised in Tables 3.4 and 3.5. For each stream of activity, there were relatively similar research and developmental processes. The research started with the identification and dissemination of suitable species; later research focused on how to make these an economically viable part of the farming system. However, in the remaining space that we have here, we want to focus mostly on nutritive value, i.e. the suite of factors that make halophytes suited to be a source of nutrients for grazing animals.

\section{TABLE 3.4 \\ Highlights in the Development of Herbaceous Species for Saltland in Southern Australia}

Year

1945-1951

1954-1959

Mid 1960s-1980s

1992-1996

1985-1995

1996-1999

1995-2013

2000-2011

\section{Activity}

Farmers attest to value of tall wheatgrass (Thinopyrum ponticum) and salt-water couch (Paspalum vaginatum) in WA. Researchers confirm their results (Teakle and Burvill 1945; Burvill and Marshall 1951).

Screening of herbaceous germplasm (69 grasses and forbs) at Kojonup WA. Puccinellia (Puccinellia ciliata) and tall wheat grass are best adapted (Rogers and Bailey 1963).

Adoption of puccinellia in WA, NSW and SA. Tall wheatgrass strongly adopted in NSW (Malcolm and Smith 1965; Fleck 1967; Hamilton 1972; Lay 1990).

Growth of puccinellia in SA is found to respond strongly to $\mathrm{N}$ fertiliser (McCarthy 1992; Herrmann 1996)

The annual legume balansa clover (Trifolium michelianum) is released by the SA Department of Agriculture in 1985; its value for waterlogged/marginally saline soils is established in VIC and WA (Rogers and Noble 1991; Rogers and West 1993; Evans 1995).

Screening of perennial grasses (30 genotypes) occurs at six NSW sites. Tall wheatgrass, puccinellia, salt-water couch and kikuyu (Pennisetum clandestinum) are best adapted (Semple et al. 1998; 2003).

A patented clone of Distichlis spicata is introduced from the US and tested in SA, WA and VIC (Leake et al. 2001; Sargeant et al. 2001). However, D. spicata that was irrigated with saline effluent had relatively poor feeding value for sheep in metabolism crates (Lymbery et al. 2013).

The annual legume messina (Melilotus seculis) is introduced from Spain and tested in SA and WA (Nichols et al. 2008). The species fails to reproduce under field conditions until suitable rhizobial symbionts are selected (Bonython et al. 2011). Messina and its rhizobium are commercially released. 


\section{TABLE 3.5 \\ Highlights in the Development of Halophytic Shrubs for Saltland in Southern Australia}

$1976-1982$

1998

$2001-2002$

2002-2009

2002-2012

2002-2008

\author{
Year \\ Late 1890 s \\ 1959 \\ 1966-1990 \\ 1968-1982

\section{Activity} \\ Value of saltbushes (Atriplex species) noted for pastoral locations (Turner 1897). \\ Planting of small-leaf bluebush (Maireana brevifolia), old man saltbush (Atriplex \\ nummularia) and creeping saltbush (Atriplex semibaccata) advocated for saltland in \\ WA wheatbelt (Smith and Malcolm 1959). \\ WA Department of Agriculture builds halophyte collection (accessions listed in \\ Malcolm and Clarke 1971; Malcolm et al. 1984). The collection peaked at more \\ than 1000 accessions. \\ 120 halophytic shrubs from five genera screened at three WA sites (Malcolm and \\ Clarke 1971). 25 genotypes selected for further work at 14 WA sites (Malcolm and \\ Swaan 1989). Outstanding genotypes are small-leaf bluebush, river saltbush \\ (Atriplex amnicola), samphire (Tecticornia pergranulata), wavy-leaf saltbush \\ (Atriplex undulata) and quailbrush (Atriplex lentiformis).
}

First 'niche' seeder built for direct seeding of saltbush. Programme of direct seeding trials commence with river saltbush, wavy-leaf saltbush, quailbrush and small leaf bluebush (Malcolm and Allen 1981; Malcolm et al. 1980, 1982, 2003; Malcolm and Swaan 1985; see also summary by Barrett-Lennard et al. 2016).

Halophytic shrubs from WA programme trialled in SA, VIC and NSW with mixed success (Lay 1990; West 1990; Barson 1994).

Saltbush establishment improved by planting commercially raised seedlings with tree planters (Barrett-Lennard et al.1991).

Saltbush criticised on the basis that the plants have low nutritive value and sheep lose condition (Warren and Casson 1994).

Importance of understorey beneath shrubs emphasised as part of the feed on offer (Barrett-Lennard and Ewing 1998).

CSIRO reviews the opportunity for animal production from saline land (Masters et al. 2001) and conducts benchmarking studies identifying halophytes and understorey species growing on saline farmland in three casestudies (Norman et al. 2002).

Grazing experiments show that some saltbush species have higher nutritional value than others, and there are differences in relative palatability within species (Norman et al. 2004; Tiong et al. 2004; Norman et al. 2008). A carbon isotope method is calibrated for the prediction of saltbush in the diet of sheep (Norman et al. 2009a). Sheep select between 10 and $40 \%$ saltbush in diet; dietary selection is related to the nutritional value of the non-salty alternative (Norman et al. 2009b; 2010a). Large producer demonstration sites are established (Thomas et al. 2009).

'Sustainable Grazing on Saline Lands' project compares productivity, environmental health and hydrological outcomes of saline land that has been revegetated with saltbush. Saltbush with understorey was shown to quadruple grazing value, half water runoff and reduce salt export by $90 \%$ (Bennett et al. 2012).

'Salty Diets' project in the CRC Salinity explores impacts of high salt diets on ruminant health and productivity. Voluntary salt intake levels for sheep documented (Masters et al. 2005b). Student projects explore various forms of exposure (in utero and with mother) to improve utilisation of saltland pastures (Blache et al. 2007; Thomas et al. 2007; Chadwick et al. 2009; Digby et al. 2010; Norman et al. 2016b). 


\section{TABLE 3.5 (Continued) \\ Highlights in the Development of Halophytic Shrubs for Saltland in Southern Australia}

\begin{tabular}{|c|c|}
\hline Year & Activity \\
\hline 2005 & $\begin{array}{l}\text { First review on importance of nutritive value in saltland pastures published; } \\
\text { subsequently updated in } 2015 \text { (Masters et al. 2005a; Masters 2015). }\end{array}$ \\
\hline 2005-2010 & $\begin{array}{l}\text { In vivo organic matter digestion of native Australian shrubs by sheep compared with } \\
\text { in vitro and in sacco predictions (Norman et al. 2010b). Near-infrared spectroscopy } \\
\text { methods redeveloped to allow for rapid and inexpensive prediction of nutritional } \\
\text { value of novel shrubs (Norman and Masters 2010c). }\end{array}$ \\
\hline 2006-2010 & $\begin{array}{l}\text { Whole farm economic modelling of saltland pastures shows that profits are increased } \\
\text { more by improvement in nutritive value than by improvement in biomass } \\
\text { (O'Connell et al. 2006). Improved nutritive value becomes a plant selection goal } \\
\text { (Monjardino et al. 2010). }\end{array}$ \\
\hline 2009-2014 & $\begin{array}{l}\text { CRC Dryland Salinity commences old man saltbush improvement programme; } \\
60,000 \text { plants, two sub-species, three sites. First commercial high nutritive value old } \\
\text { man saltbush clone ('Anameka }{ }^{\mathrm{TM}} \text { ') released in } 2014 \text { (Norman et al. 2016a). }\end{array}$ \\
\hline 2004-2019 & $\begin{array}{l}\text { The role of saltbush as an antioxidant to improve sheep health and meat quality is explored } \\
\text { (Pearce et al. 2005; Pearce et al. 2010; Fancote et al. 2013; Norman et al. 2019). }\end{array}$ \\
\hline 2013 & $\begin{array}{l}\text { Interactions between plants and environment, and impact on feeding value reviewed } \\
\text { (Norman et al. 2013). Oxalate found to accumulate in leaves of old man saltbush } \\
\text { plants fed nitrate but not ammonium (Al Daini et al. 2013). }\end{array}$ \\
\hline 2015-2018 & $\begin{array}{l}\text { Ability of halophytic shrubs to reduce methane emissions from sheep investigated } \\
\text { (Li et al. 2016; 2018). }\end{array}$ \\
\hline 2019-2022 & $\begin{array}{l}\text { CSIRO's 'No More Gaps' project develops agronomic packages for management of } \\
\text { high nutritive value old man saltbushes and seed coatings for direct seeding. }\end{array}$ \\
\hline
\end{tabular}

Halophytes have been defined as plants that can complete their life cycles at salt concentrations in the soil solution greater than 200 millimoles per litre (i.e. $\mathrm{EC}_{\mathrm{w}}$ values $>20 \mathrm{dS} \mathrm{m}^{-1}$ ) (Flowers and Colmer, 2015); they have strengths and weaknesses as forages (Masters et al. 2005a; Norman et al. 2013). Many species particularly from the family Amaranthaceae are able to grow in saline environments because they use salt for the osmotic adjustment of cell vacuoles (Flowers and Colmer, 2015). This can be a problem for the use of these plants as forages because the accumulated salt has no nutritive value for ruminants and must be excreted (Masters et al. 2005a; Norman et al. 2013). Sheep grazing halophytes need to be supplied with large amounts of fresh water (they can drink up to $12 \mathrm{~L}$ of water per day), and they will decrease their feed intake as the concentration of the salt in the diet increases (Warren et al. 1990; Masters et al. 2005b). Other disadvantages of halophytes are: (a) they can have low digestibility of the organic matter (which means that they have low energy concentrations for grazing animals), (b) they can be unpalatable, and (c) they can accumulate high (>6\% DM) concentrations of potentially toxic compounds like oxalate in their leaves (Malcolm et al. 1988; Norman et al. 2004; Masters et al. 2007; Masters 2015). In old man saltbush (Atriplex nummularia), accumulation of oxalate was shown to be associated with the uptake of nitrate, as opposed to ammonium, by the plants (Al Daini et al. 2013). 
On the other hand, halophytes can have nutritional benefits for animals. Many halophytic species osmotically adjust the cellular cytoplasm through the accumulation of small molecular weight 'compatible solutes' such as glycine-betaine (Storey et al. 1977). These compounds are rich in N, which can be converted into protein in the rumen if the animals have sufficient energy, often from other feed sources, in the diet (Masters et al. 2005a). Finally, saltland pastures may assist ruminants to assist with oxidative damage associated with heat stress. Vitamin E deficiency and associated muscular myopathy is widespread in sheep grazing dry pastures and crop residues during the hot summer and autumn seasons in Western Australia (White and Rewell 2007). Research in the 2000s found that leaves of halophytes like saltbush (Atriplex species) are an excellent source of vitamin E and sheep grazing saltbush are not susceptible to muscular myopathy (Pearce et al. 2005). Furthermore, access to saltbush leaves for several weeks can provide enough vitamin $\mathrm{E}$ for lambs to maintain health through autumn feedlotting and improve meat quality (Pearce et al. 2010; Fancote et al. 2013). In addition to vitamin E, saltbushes are rich in the minerals associated with antioxidant pathways (Norman et al. 2019).

Our modern understanding is that halophytic shrubs like saltbushes (Atriplex spp.) can be an important part of the fodder supply on a farm. However, best animal and economic performance will occur if farmers follow a number of principles. These include:

1. Graze the saltland pasture during the most feed-limited time of year - in southern Australia, this is often in summer and autumn when senesced crops and annual pastures provide the most of the feedbase (O'Connell et al. 2006).

2. Establish pastures using palatable high nutritional value species on moderately to highly saline landscapes, not severely-extremely saline landscapes. Feed intake is limited by high salt in the diet, so the most productive systems often contain a mixed range of species such as rows of perennial halophytes accompanied by an understorey of more salt-sensitive annual pasture plants (e.g. Norman et al. 2010a). The system is not suited to soils of extreme salinity: the euhalophytes (e.g. Tecticornia pergranulata) that grow in these environments accumulate too much salt in their foliage (often accounting for $\sim 40 \%$ of shoot DM) and these soils will not support the required lowsalt understorey. Naturally occurring annual pasture species can be used as indicators of the better soils (Bennett and Barrett-Lennard 2013).

3. Train the animals to use the feed; they may not recognise that novel shrubs are food. Training is often achieved by introducing inexperienced lambs to the feed while still joined to their more experienced mothers (Norman et al. 2016b). In utero exposure of lambs provides another opportunity to improve the intake and utilisation of saltbush (Chadwick et al. 2009).

4. Use it or lose it. The growth of long-lived, woody perennial shrubs slows as the plants reach a critical leaf area and move into their reproductive phase. They will drop excess leaves when water-stressed. A complete annual defoliation improves plant growth rates and produces new leaves of higher nutritional value (Wilmot and Norman 2006).

5. Supply animals with large amounts of cool fresh water. 


\subsection{DEVELOPMENT OF ANAMEKA ${ }^{\text {TM }}$ SALTBUSH}

Whole-farm economic modelling in 2006 suggested that increasing the metabolisable energy value of saltland pastures was the key to improving the profitability of systems (O'Connell et al. 2006). Germplasm of Atriplex nummularia (old man saltbush) was collected from across the native range in Australia and genotypes from 27 populations and two subspecies were compared at three research sites. At the same time, methods were developed to allow for the rapid and inexpensive screening of the energy value of the shrubs to grazing animals (Norman et al. 2010b,c). Sheep were used to identify plants that were consistently preferred; these plants tended to have higher energy values and lower sulphur (Norman et al. 2009; 2015). Over 8 years in a sequence of on-farm experiments, the team identified old man saltbush genotypes with $20 \%$ higher organic matter digestibility, greater acceptability to sheep and up to eight times more edible biomass production than the mean of the collection (Norman et al. 2016). In 2015, the first clonal cultivar was commercialised by CSIRO (cv. Anameka ${ }^{\mathrm{TM}}$ ). Whole-farm economic analysis suggests that Anameka, planted on soils that are marginal for crop production, can double the profitability of saltbush plantations on farms (Monjardino et al. 2010). Over two million Anameka ${ }^{\mathrm{TM}}$ shrubs, sold as clonal cuttings, have now been planted by over 200 Australian farmers. The team are now developing elite seed lines and methods to aid saltbush establishment from seeds.

\subsection{ELECTROMAGNETIC INDUCTION AS A TOOL IN CONDUCTING FIELD TRIALS}

Any student of the saline agricultural literature will soon find that many plant experiments are conducted under controlled conditions (e.g. salt flushed lysimeters, nutrient solution cultures, etc.) but fewer are conducted under general field conditions. This occurs despite the fact that such research is generally intended to produce better outcomes in the field. One of the reasons for this is that soil salinity is often spatially and temporally heterogenous and it is, therefore, difficult to layout and block the plots making up field trials in a manner that gives appropriate statistical rigour. For researchers in Australia, this changed in the 1980s because of the availability of instruments like the EM38 (Geonics Ltd) and the DualEM that use the principle of electromagnetic induction to measure variation in the apparent electrical conductivity of the soil $\left(\mathrm{EC}_{\mathrm{a}}\right)$. Electromagnetic induction has been used at a range of scales to survey spatial variation in salinity for a number of decades (Spies and Woodgate 2005). The recent innovation has been to recognise that at the plot scale measurements of $\mathrm{EC}_{\mathrm{a}}$ can be correlated with measures of soil $\mathrm{EC}_{1: 5}$ and/or the salinity of the soil solution and that these measures can then be used statistically to correct grain yields for variation in soil salinity across a site (e.g. Setter et al. 2016; Asif et al. 2018).

An example of the use of the EM38 for this purpose can be seen in the work of Setter et al. (2016). These researchers tested the variation in grain yield of 90 wheat and 27 barley cultivars in separate experiments in a saline field in the wheatbelt of Western Australia in two growing seasons 2009 and 2011. Experiments of this kind 


\section{TABLE 3.6}

\section{Significance ( $P$-Value) of the Terms Used in Statistical Models to Account for Variation in Grain Yield in the Field}

$\begin{array}{lccccc}\text { Crop } & \text { Year } & \text { EM38 (June) } & \text { Row } & \text { Column } & \text { Genotype } \\ \text { Wheat } & 2009 & <0.001 & 0.0418 & <0.001 & <0.001 \\ & 2011 & \text { Ns } & <0.001 & 0.0141 & <0.001 \\ \text { Barley } & 2009 & <0.001 & 0.0062 & 0.0036 & <0.001 \\ & 2011 & <0.001 & \text { Ns } & \text { Ns } & <0.001\end{array}$

Source: After Setter et al. 2016.

are normally conducted using a rectangular array of plots indexed by rows and columns, with replication along the rows and columns. This enables a statistical analysis of grain yield that takes account of linear variation in the direction of increasing rows and columns. However, in this work, the researchers also measured $\mathrm{EC}_{\mathrm{a}}$ values with an EM38 in June (about a month after crop establishment). The significance of the linear effects of EM38, row and column effects on the variation, and the final impact of these covariates on the significance of cultivar effects are summarised in Table 3.6. It can be seen that there were highly significant effects of EM38 reading $(P<0.001)$ for three of the four experiments, but the linear effects of row and column were less significant (only one of the four effects in each case had $P<0.001$ ). Thankfully however, the combination of all covariates was sufficient for the effects of genotype to be significant at $P<0.001$ in all four experiments, and the research team was able to conclude that the variables associated with high grain yield in this environment were genetic; successful cultivars were adapted to local conditions, had high salt-tolerance and early flowering (Setter et al. 2016).

\subsection{SALINE FUTURES AND CLIMATE CHANGE}

Will climate change make salinity outcomes better or worse in southern Australia? The answer to this question will depend on the primary cause of salinity. For soils affected by the presence of shallow water-tables, the risk of salinity may well be ameliorated overall by the drier conditions that are likely to occur. Indeed, there is already some evidence for this. Since 1975, annual rainfall has decreased by $10-25 \%$ over much of the southwest of Australia (McFarlane et al. 2020). About 700 bores across the southwest of Australia have a sufficiently long record of measurement to estimate groundwater levels trends before and after 2000. Two-thirds of all monitored bores had rising groundwater levels prior to 2000 , but only $40 \%$ rose between 2000 and 2012 (McFarlane et al. 2020). The implication is clear: climate change may help ameliorate dryland salinity.

However, the effects of climate change on cropped soils affected by transient salinity in southern Australia, is expected to be different. For these dispersive alkaline soils, salt has accumulated over hundreds of years from rainfall; there is no 
expectation that climate change will decrease the concentration of salt in these soils, and if the soils become drier, then the salinity of the soil solution will increase. This will affect the growth of annual crops and pastures, but particularly those that are most salt sensitive. The adverse effects can be expected to be greatest for salt sensitive crops like field peas, will be lower for wheat, and least for more tolerant crops like barley and canola.

We conclude on a challenging note. The species developed for saltland revegetation across southern Australia may have a broader application than saltland alone. Many of these species are endemic to arid and well as saline environments. With climate change, we expect that the growth of traditional crops and pastures will become riskier in the driest agricultural areas of southern Australia (annual average rainfall less than $280 \mathrm{~mm}$ ). What could this land be used for? Modelling suggests that one of the most effective strategies that Australian farmers use to manage risk is to diversify their farms across crop and livestock enterprises (Ghahramani et al. 2019). We believe that much of this land could be suited to sheep and cattle breeding systems based on the growth of elite perennial halophytic shrubs augmented by perennial grasses and short-season annual legumes. The eventual area of these permanent shrub-based pasture farming systems could extend over millions of hectares. Researchers in partnership with farmers need to use the skills and expertise that have been honed in the building of saltland pastures to explore this exciting (but also daunting) new opportunity.

\section{ACKNOWLEDGEMENTS}

We acknowledge support and contributions from many co-funders and collaborators across many projects. This includes participants in the CRC Plant Based Management of Dryland Salinity and the CRC Future Farm Industries. Various projects have received support from the Australian Government Department of Agriculture, Water and the Environment, Meat and Livestock Australia, Australian Wool Innovation, the Grains Research and Development Corporation and the Australian Centre for International Agricultural Research. Many Australian agencies have contributed to this research, including teams from CSIRO, WA Department of Primary Industries and Regional Development, New South Wales Department of Primary Industries, WA Department of Biodiversity, Conservation and Attractions, Department of Water Land and Biodiversity Conservation in South Australia and the South Australian Research and Development Institute, University of Western Australia, Curtin University and Murdoch University. We are very grateful to all the Australian farmers who have hosted and support our research and the team at Chatfield's Tree Nursery. We are grateful for the helpful comments of Dr Richard George on this manuscript.

\section{ENDNOTE}

1. The names of Australian States are abbreviated as follows: New South Wales (NSW), Victoria (VIC), Queensland (QLD), South Australia (SA), Western Australia (WA) and Tasmania (TAS). 


\section{REFERENCES}

ABS (2002) Salinity on Australian farms. Australian Bureau of Statistics, Canberra (www. abs.gov.au/AUSSTATS/abs@.nsf/Lookup/4615.0Main+Features12002)

Al Daini, H, Norman, HC, Young P and Barrett-Lennard, EG (2013) The source of nitrogen $\left(\mathrm{NH}_{4}^{+}\right.$or $\left.\mathrm{NO}_{3}^{-}\right)$affects the concentration of oxalate in the shoots and the growth of Atriplex nummularia (oldman saltbush). Functional Plant Biology 40, 1057-1064.

Asif MA, Schilling RK, Tilbrook J, Brien C, Dowling K, Rabie H, Short L, Trittermann C, Garcia A, Barrett-Lennard EG, Berger B, Mather DE, Gilliham M, Tester M, Fleury D, Roy SJ and Pearson AS (2018) Identification of novel salt tolerance QTL in the Excalibur $\times$ Kukri doubled haploid $(\mathrm{DH})$ wheat population. Theoretical and Applied Genetics 131, 2179-2196.

Barrett-Lennard EG (1986) Effects of waterlogging on the growth and $\mathrm{NaCl}$ uptake by vascular plants under saline conditions. Reclamation and Revegetation Research 5, 245-261.

Barrett-Lennard EG (2003) The interaction between waterlogging and salinity in higher plants: causes, consequences and implications. Plant and Soil 253, 35-54.

Barrett-Lennard E and Ewing M (1998) Saltland Pastures? They are feasible and sustainable - we need a new design. In: Proceedings of the 5th National Conference on Productive Use and Rehabilitation of Saline Lands, 10-12 March, Tamworth, pp. 160-161.

Barrett-Lennard E, Frost F, Vlahos S and Richards N (1991) Revegetating salt-affected land with shrubs. Journal of Agriculture of Western Australia 32, 124-129.

Barrett-Lennard EG, George RJ, Hamilton G, Norman HC and Masters DG (2005) Multidisciplinary approaches suggest profitable and sustainable farming systems for valley floors at risk of salinity. Australian Journal of Experimental Agriculture 45, 1415-1424.

Barrett-Lennard EG and Shabala SN (2013) The waterlogging/salinity interaction in higher plants revisited - focusing on the hypoxia-induced disturbance to $\mathrm{K}^{+}$homeostasis. Functional Plant Biology 40, 872-882.

Barrett-Lennard EG, Bennett SJ and Colmer TD (2008) Standardising terminology for describing the level of salinity in soils. 2nd International Salinity Forum, Adelaide, 31 March - 3 April, 4 pp.

Barrett-Lennard EG, Norman HC and Dixon K (2016) Improving saltland revegetation through understanding the 'recruitment niche': potential lessons for ecological restoration in extreme environments. Restoration Ecology 24, S91-S97.

Bennett D and George R (2008) Long term monitoring of groundwater levels at 24 sites in Western Australia shows that integrated farm forestry systems have little impact on salinity. Proceedings of the 2nd International Salinity Forum, 31 March - 3 April, Adelaide, Australia.

Bennett SJ and Barrett-Lennard EG (2013) Predictions of watertable depth and soil salinity levels for land capability assessment using site indicator species. Crop and Pasture Science 64, 285-294.

Bennett SJ, Barrett-Lennard EG and Colmer TD (2009) Salinity and waterlogging as constraints to saltland pasture production: a review. Agriculture, Ecosystems and Environment 129, 349-360.

Blache D, Grandison MJ, Masters DG, Dynes RA, Blackberry MA and Martin GB (2007). Relationships between metabolic endocrine systems and voluntary feed intake in Merino sheep fed a high salt diet. Australian Journal of Experimental Agriculture 47, 544-550.

Bonython AL, Ballard RA, Charman N, Nichols PGH and Craig AD (2011) New strains of rhizobia that nodulate regenerating messina (Melilotus siculus) plants in saline soils. Crop and Pasture Science 62, 427-436.

Burvill GH (1956) Salt land survey, 1955. Journal of Agriculture of Western Australia 5, $113-120$. 
Burvill GH and Marshall AJ (1951) Paspalum vaginatum or seashore paspalum. Journal of Agriculture of Western Australia, 28, 191-194.

Chadwick MA, Vercoe PE, Williams IH and Revell DK (2009) Dietary exposure of pregnant ewes to salt dictates how their offspring respond to salt. Physiology and Behavior 97, 437-445.

Conacher AJ, Combes PL, Smith PA and McLellan RC (1983) Evaluation of throughflow interceptors for controlling secondary soil and water salinity in dryland agricultural areas of southwestern Australia: I. Questionnaire surveys. Applied Geography 3, 29-44.

Dawes WR, Stauffacher M and Walker GR (2000) Calibration and Modelling of Groundwater Processes in The Liverpool Plains. CSIRO Land and Water Technical Report 5/00, Canberra, Australia.

Digby SN, Masters DG, Blache D, Hynd PI and Revell DK (2010) Offspring born to ewes fed high salt during pregnancy have altered responses to oral salt loads. Animal 4, 81-88.

Evans P (1995) Developing pasture legumes for waterlogged/salt affected areas in medium rainfall zones of Western Australia. Final Report, Project DAW 164, International Wool Secretariat, $20 \mathrm{pp}$.

Fancote CR, Vercoe PE, Pearce KL, Williams IH and Norman HC (2013) Backgrounding lambs on saltbush provides an effective source of Vitamin $E$ that can prevent Vitamin $\mathrm{E}$ deficiency and reduce the incidence of subclinical nutritional myopathy during summer and autumn. Animal Production Science 53, 247-255.

Fleck BC (1967) A note on the performance of Agropyron elongatum (Host.) Beauv. and Puccinellia (Parl.) sp. in revegetation of saline areas. Journal of the Soil Conservation Service of NSW 23, 261-269.

Flowers TJ and Colmer TD (2015) Plant salt tolerance: adaptations in halophytes. Annals of Botany $115,327-331$.

George R, McFarlane D and Nulsen B (1997) Salinity threatens the viability of agriculture and ecosystems in Western Australia. Hydrogeology Journal 5, 6-21.

George RJ, Clarke CJ and Hatton T (2001) Computer-modelled groundwater response to recharge management for dryland salinity control in Western Australia. Advances in Environmental Monitoring and Modelling 2, 3-35.

Ghahramani A, Howden, MS, del Prado A, Thomas DT, Moore AD, Ji B (2019) Climate change impact, adaptation and mitigation in temperate grazing systems: a review. Sustainability $11,7224$.

Ghassemi F, Jakeman AJ and Nix HA (1995) Salinisation of Land and Water Resources: Human Causes, Extent, Management and Case Studies. University of New South Wales Press Ltd, Sydney, pp. 526.

Greenwood EAN, Klein L, Beresford JD and Watson GD (1985) Differences in annual evaporation between grazed pasture and Eucalyptus species in plantations on a saline farm catchment. Journal of Hydrology 78, 261-278.

Hamilton GJ (1972) Investigations into reclamation of dryland saline soils. Journal of the Soil Conservation Service of NSW 28, 191-211.

Hatton TJ and Nulsen RA (1999) Towards achieving functional ecosystem mimicry with respect to water cycling in southern Australian agriculture. Agroforestry Systems 45, 203-214.

Herrmann T (1996) Puccinellia - maximum productivity from saltland. In: Proceedings of the 4th National Conference on Productive Use and Rehabilitation of Saline Lands, 25-30 March, Albany. Promaco Conventions Pty Ltd, Canning Bridge, pp. 297-302.

Hingston FJ and Gailitis V (1975) The geographic variation of salt precipitated over Western Australia. Australian Journal of Soil Research 14, 319-335.

Latta RA, Blacklow LJ and Cocks PS (2001) Comparative soil water, pasture production, and crop yields in phase farming systems with lucerne and annual pasture in Western Australia. Australian Journal of Agricultural Research 52, 295-303. 
Latta RA, Cocks PS and Matthews C (2002) Lucerne pastures to sustain agricultural production in southwestern Australia. Agricultural Water Management 53, 99-109.

Lay B (1990) Salt land revegetation: a South Australian overview. In: Revegetation of Saline Land (edited by BA Myers and DW West), Institute for Irrigation and Salinity Research, Tatura, Victoria, pp. 15-20.

Leake J, Barrett-Lennard E, Yensen N and Prefumo J (2001) NyPa Distichlis cultivars: rehabilitation of highly saline areas for forage, turf and grain. Final Report Project RAS98-74. Rural Industries Research and Development Corporation, Canberra.

Li X, Young P and Norman HC (2016) Nitrate and sulphate accumulating saltbush reduces methane emissions in the ANKOM fermentation system. In: '6th Greenhouse Gas and Animal Agriculture Conference, Melbourne'. p. 102.

Li X, Norman HC, Hendry JK, Hulm E, Young P, Speijers J and Wilmot MG (2018) The impact of supplementation with Rhagodia preissii and Atriplex nummularia on wool production, mineral balance and enteric methane emissions of Merino sheep. Grass and Forage Science 73, 381-391.

Lymbery AJ, Kay GD, Doupe RG, Partridge GJ and Norman HC (2013) The potential of a salt-tolerant plant (Distichlis spicata cv. NyPa Forage) to treat effluent from inland saline aquaculture and provide livestock feed on salt-affected farmland. Science of the Total Environment 445, 192-201.

Malcolm CV and Allen RJ (1981) The Mallen niche seeder for plant establishment on difficult sites. Australian Rangeland Journal 3, 106-109.

Malcolm CV and Clarke AJ (1971) Progress Report No. 1. Collection and testing of forage plants for saline and arid areas. Technical Bulletin No. 8, Department of Agriculture of Western Australia, South Perth, 39 pp.

Malcolm CV and Smith ST (1965) Puccinellia - outstanding saltland grass. Journal of Agriculture of Western Australia 6, 153-156.

Malcolm CV and Swaan TC (1985) Soil mulches and sprayed coatings and seed washing to aid chenopod establishment on saline soil. Australian Rangeland Journal 7, 22-28.

Malcolm CV and Swaan TC (1989) Screening shrubs for establishment and survival on salt-affected soils in south-western Australia. Technical Bulletin 81, Department of Agriculture of Western Australia, South Perth, 35 pp.

Malcolm CV, Swaan TC and Ridings HI (1980) Niche seeding for broad scale forage shrub establishment on saline soils. In: International Symposium on Salt Affected Soils, Symposium Papers. Central Soil Salinity Research Institute, Karnal, India, pp. 539-544.

Malcolm CV, Clarke AJ and Swaan TC (1984) Plant collections for saltland revegetation and soil conservation. Technical Bulletin 65, Department of Agriculture of Western Australia, South Perth.

Malcolm CV, Hillman BJ, Swaan TC, Denby C, Carlson D and D'Antuono M (1982) Black paint soil amendment and mulch effects on chenopod establishment in a saline soil. Journal of Arid Environments 5, 179-189.

Malcolm CV, Lindley VA, O'Leary JW, Runciman HV and Barrett-Lennard EG (2003) Halophyte and glycophyte salt tolerance at germination and the establishment of halophyte shrubs in saline environments. Plant and Soil 253, 171-185.

Malcolm CV, Clarke AJ, D'Antuono MF and Swaan TC (1988) Effects of plant spacing and soil conditions on the growth of five Atriplex species. Agriculture, Ecosystems and Environment 21, 265-279.

Masters DG (2015). Assessing the feeding value of halophytes. In: Halophytic and Salt tolerant Feedstuffs: Impacts on Nutrition, Physiology and Reproduction of Livestock (edited by HM El Shaer and VR Squires). CRC Press. pp. 89-105.

Masters DG, Norman HC and Dynes RA (2001) Opportunities and limitations for animal production from saline land. Asian-Australasian Journal of Animal Sciences 14, 199-211. 
Masters DG, Norman HC and Barrett-Lennard EG (2005a) Agricultural systems for saline soil: the potential role of livestock. Asian-Australasian Journal of Animal Science 18, 296-300.

Masters DG, Rintoul AJ, Dynes RA, Pearce KL and Norman HC (2005b) Feed intake and production in sheep fed diets high in sodium and potassium. Australian Journal of Agricultural Research 56, 427-434.

Masters DG, Benes SE, and Norman HC (2007) Biosaline agriculture for forage and livestock production. Agriculture, Ecosystems and Environment 119, 234-248.

McCarthy DG (1992) Salt tolerant grasses - mediterranean environment. In: National Workshop on Productive Use of Saline Land (edited by TN Herrmann), South Australian Department of Agriculture, pp. 28-35.

McFarlane D, George R, Ruprecht J, Charles S and Hodgson G (2020) Runoff and groundwater responses to climate change in south west Australia. Journal of the Royal Society of Western Australia 103, 9-27.

Monjardino M, Revell DK and Pannell DJ (2010) The potential contribution of forage shrubs to economic returns and environmental management in Australian dryland agricultural systems. Agricultural Systems 103, 187-197.

Nichols PGH, Rogers ME, Craig AD, Albertsen TO, Miller SM, McClements DR, Hughes SJ, D'Antuono MF and Dear BS (2008) Production and persistence of temperate perennial grasses and legumes at five saline sites in southern Australia. Australian Journal of Experimental Agriculture 48, 536-552.

Norman HC, Dynes RA and Masters DG (2002) An integrated approach to the planning, training and management for the revegetation of saline land. Final Report to State Salinity Council. CSIRO Livestock Industries (in collaboration with the Saltland Pastures Association), Wembley WA, $17 \mathrm{pp}$.

Norman HC, Freind C, Masters DG, Rintoul AJ, Dynes RA and Williams IH (2004) Variation within and between two saltbush species in plant composition and subsequent selection by sheep. Australian Journal of Agricultural Research 55, 999-1007.

Norman HC, Masters DG, Wilmot MG and Rintoul AJ (2008) Effect of supplementation with grain, hay or straw on the performance of weaner Merino sheep grazing old man (Atriplex nummularia) or river (Atriplex amnicola) saltbush. Grass and Forage Science 63, 179-192.

Norman HC, Wilmot MG, Thomas DT, Masters DG and Revell DK (2009a) Stable carbon isotopes accurately predict diet selection by sheep fed mixtures of C-3 annual pastures and saltbush or C-4 perennial grasses. Livestock Science 121, 162-172.

Norman HC, Revell DK and Masters DG (2009b) Sheep avoid eating saltbushes with high sulphur concentrations. Proceedings of the XIth International Symposium on Ruminant Physiology (ISRP), Clermont-Ferrand, France, September 6 to 9.

Norman HC, Wilmot MG, Thomas DT, Barrett-Lennard EG and Masters DG (2010a) Sheep production, plant growth and nutritive value of a saltbush-based pasture system subject to rotational grazing or set stocking. Small Ruminant Research 91, 103-109.

Norman HC, Revell DK, Mayberry DE, Rintoul AJ, Wilmot MG and Masters DG (2010b) Comparison of in vivo organic matter digestion of native Australian shrubs by sheep to in vitro and in sacco predictions. Small Ruminant Research 91, 69-80.

Norman HC and Masters DG (2010c) Predicting the nutritive value of saltbushes (Atriplex spp) with near infrared reflectance spectroscopy. In Proceedings of the International Conference on Management of Soil and Groundwater Salinization in Arid Regions, 11-14 January 2010, Muscat Oman. Edited by M. Ahmed and S. Al-Rawahy, SQU Press, Muscat, Oman, pp. 51-57.

Norman HC, Masters DG and Barrett-Lennard EG (2013) Halophytes as forages in saline landscapes: interactions between plant genotype and environment change their feeding value to ruminants. Environmental and Experimental Botany 92, 96-109. 
Norman HC, Hulm E and Wilmot MG (2016a) Improving the feeding value of old man saltbush for saline production systems in Australia. In: Halophytic and Salt tolerant Feedstuffs: Impacts on Nutrition, Physiology and Reproduction of Livestock (edited by HM El Shaer and VR Squires) CRC Press, pp. 79-86.

Norman HC, Thomas D, Wilmot MG and Revell DK (2016b) Programming lambs to improve utilisation of novel forages. Australian Society of Animal Production Biannual Conference, Adelaide, Australia 4-8 July 2016.

Norman HC, Duncan EG and Masters DG (2019) Halophytic shrubs accumulate minerals associated with antioxidant pathways. Grass and Forage Science 74, 345-355.

Nulsen RA (1981) Critical depth to saline groundwater in non-irrigated situations. Australian Journal of Soil Research 19, 83-86.

O'Connell M, Young J and Kingwell R (2006) The economic value of saltland pastures in a mixed farming system in Western Australia. Agricultural Systems 89, 371-389.

Pearce KL, Masters DG, Jacob RH, Smith G and Pethick DW (2005) Plasma and tissue a-tocopherol concentrations and meat colour stability in sheep grazing saltbush (Atriplex spp.). Australian Journal of Agricultural Research 56, 663-672.

Pearce KL, Norman HC and Hopkins DL (2010) The role of saltbush-based pasture systems for the production of high quality sheep and goat meat. Small Ruminant Research 91, $29-38$

Rengasamy P (2002) Transient salinity and subsoil constraints to dryland farming in Australian sodic soils: an overview. Australian Journal of Experimental Agriculture 42, 351-361.

Rengasamy P (2006). World salinization with emphasis on Australia. Journal of Experimental Botany 57, 1017-1023.

Rogers AL and Bailey ET (1963) Salt tolerance trials with forage plants in south-western Australia. Australian Journal of Experimental Agriculture and Animal Husbandry 3, $125-130$.

Rogers ME and Noble CL (1991) The effect of $\mathrm{NaCl}$ on the establishment and growth of balansa clover (Trifolium michelianum Savi Var. balansae Boiss.). Australian Journal of Agricultural Research 42, 847-857.

Rogers ME and West DW (1993) The effects of rootzone salinity and hypoxia on shoot and root growth in Trifolium species. Annals of Botany 72, 503-509.

Sargeant MR, Rogers ME, White RE and Batey T (2001) Distichlis spicata - a grass for highly saline areas. In: Wanted - Sustainable Futures for Saline Lands - Proceedings of the 7th National Conference on Productive Use and Rehabilitation of Saline Lands, Launceston, TAS, 20-33 March, pp. 212-213.

Semple W, Beale G, Cole I, Gardiner T, Glasson A, Koen T, Parker B, Phillips B, Reynolds K, Thearle L and the Windellama Landcare Group (1998). Evaluation of perennial grasses for saline site revegetation. In: Managing Saltland into the 21st Century: Dollars and Sense from Salt - Proceedings of 5th National Conference on the Productive Use and Rehabilitation of Saline Lands (edited by NE Marcar and AKM Afzal Hossain), PNM Editorial Publications, Canberra, pp. 157-159.

Semple WS, Cole IA and Koen TB (2003). Performance of some perennial grasses on severely salinised sites of the inland slopes of New South Wales. Australian Journal of Experimental Agriculture 43, 357-371.

Setter TL, Waters I, Stefanova K, Munns R and Barrett-Lennard EG (2016) Salt tolerance, date of flowering and rain affect the productivity of wheat and barley on rainfed saline land. Field Crops Research 194, 31-42.

Smith ST and Malcolm CV (1959) Bringing wheatbelt saltland back into production. Journal of Agriculture of Western Australia 8, 263-267.

Spies B and Woodgate P (2005) Salinity Mapping Methods in the Australian Context. Report for the Programs Committee of Natural Resource Management Ministerial Council, 
through Land and Water Australia and the National Dryland Salinity Program. Department of the Environment and Heritage; and Agriculture, Fisheries and Forestry, Canberra, $47 \mathrm{pp}$.

Storey R, Ahmad N and Wyn Jones RG (1977) Taxonomic and ecological aspects of the distribution of glycinebetaine and related compounds in plants. Oecologia 27, 319-332.

Teakle LJH and Burvill GH (1938) The movement of soluble salts in soils under light rainfall conditions. Journal of Agriculture of Western Australia 15, 218-245.

Teakle LJH and Burvill GH (1945) The management of salt lands in Western Australia. Journal of Agriculture of Western Australia 22, 87-93.

Thomas DT, Rintoul AJ and Masters DG (2007) Sheep select combinations of high and low sodium chloride, energy and crude protein feed that improve their diet. Applied Animal and Behaviour Science 105, 140-153.

Thomas DT, White CL, Hardy J, Collins JP, Ryder A and Norman HC (2009) An on-farm evaluation of the capability of saline land for livestock production in southern Australia. Animal Production Science 49, 79-83.

Tiong MK, Masters DG, Norman HC, Milton JTB and Rintoul AJ (2004) Variation within and between four halophytic shrub species collected from five saline environments. Animal Production in Australia 25, 327.

Turner F (1897) West Australian saltbushes. In: The West Australian Settler's Guide and Farmer's Handbook, Part III, Chapter II (edited by L Lindley-Cowen), E.S. Wigg and Son, Printers, pp. 418-431.

Warren BE, Bunny CJ and Bryant ER (1990) A preliminary examination of the nutritive value of four saltbush (Atriplex) species. Proceedings of the Australian Society of Animal Production 18, 424-427.

Warren BE and Casson T (1994) Sheep and saltbush - are they compatible? Proceedings of the 3rd national workshop on Productive Use of Saline Land, Echuca 15-17 March, Murray Darling Basin Commission and Salt Action, pp. 125-129.

West DW (1990) Revegetation of saline lands - perspectives from Victoria. In: Revegetation of Saline Land (edited by BA Myers and DW West), Institute for Irrigation and Salinity Research, Tatura, Victoria, pp. 5-11.

White CL and Rewell L (2007) Vitamin E and selenium status of sheep during autumn in Western Australia and its relationship to the incidence of apparent white muscle disease. Australian Journal of Experimental Agriculture 47, 535-543.

Wilmot MG and Norman HC (2006 July). Saltbush biomass in a saline grazing system - use it or lose it. Proceedings of the Australian Society of Animal Production 26th Biennial Conference Science and Industry - Hand in glove. Perth, Australia. 10-14.

Wood WE (1924) Increase of salt in soil and streams following the destruction of native vegetation. Journal of the Royal Society of Western Australia 10, 35-47. 


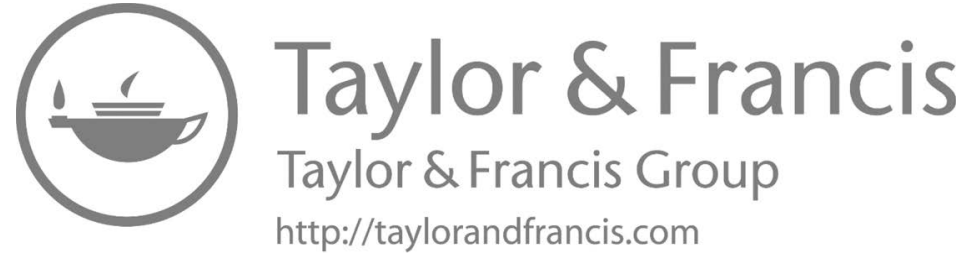

